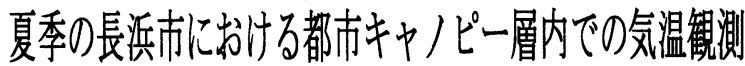

\section{Observations of Air Temperature in the Urban Canopy Layer in Naggahama-city}

\author{
桐原 博人*、藤野 毅**、三上 岳彦* \\ Hirohito KIRIHARA $^{*}$, Takeshi FUJINO ${ }^{* *}$, Takehiko MIKAMI *
}

\begin{abstract}
The observation was carried out in Nagahama-city, Shiga-prefecture for two days in the end of July, 1996. Starting from the shore of a lake, in the section of about $3800 \mathrm{~m}$ to an edge of urban district, we set a self-registering thermometer at nine points along the prefectual road that was vertical to the shore of a lake, and air temperatures were continuously measured in the urban canopy layer. Also, we set six self-registering thermometers in the tower of NTT at the center of city and vertical air temperatures were continuously measured in the lower urban boundary layer. Anemometers were set on the tower of NTT, Nagahama City Hall and the park in the shore of a lake. Amounts of global solar radiation and atmospheric radiation were measured at Nagahama City Hall. During observation period, weather was almost clear. From cross-sectional figures of air temperature, heat island was formed in the center of Nagahama-city. The daily maximum temperature became about 16:00 J.S.T. from diurnal variations of air temperature in Nagahama-city. Lake breeze blew from about 9:00 J.S.T. to about 17:00 J.S.T., and air temperature in the urban canopy layer was calm, but it was mitigated by lake breeze.
\end{abstract}

KEYWORDS; heat island, lake-land breeze, urban canopy layer, heat environment

\section{1.はじめに}

滋賀県長浜市は、琵琶湖の北東部に位置する湖岸に面した小規模都市である。長浜市の周囲は、伊吹山を はじめとする海抜 $600 \mathrm{~m}$ を越すいくつかの山脈に囲まれた複雑な地形をなしている。琵琶湖周辺域では臨 海域の海陸風と同じように一般風の弱い日には、湖陸風の吹く環境にある。都市のヒートアイランドに対す る海陸風の影響に関する研究は、これまで多く報告されているが（たとえば藤野ら，1993; 藤野ら，1996b ; 高木・北田，1996）、湖陸風のような海陸風よりもさらに弱い局地風系を形成する水面の熱環境が都市の ヒートアイランドに及ぼす研究は、あまりなされていない。琵琶湖プロジェクトの一環として藤野ら（1996a） は “風の通り道”として市街地スケールの数值モデルから長浜市内のストリートキャニオンについて、その 熱環境評価を試みている。また藤野ら（1997）は、規模の小さい住宅街を対象に気象観測を行い、都市のバ ックグラウンドの影響や都市キャノピー層内外の放熱・蓄熱特性について調べている。

本研究では住環境に密接した都市キャノピー層に注目して、湖風が都市キャノピー層内の気温の成立にど のような影響を及ぼしているのか、キャノピー層内の気温断面を詳細に調べることで考察した。

\footnotetext{
* 東京都立大学理学部地理学科

Department of Geography, Faculty of Science, Tokyo Metropolitan University

** 埼玉大学大学院理工学研究科

Graduate School of Science and Engineering, Saitama University
} 


\section{2. 気象観測}

気象観測は、滋賀県長浜市で 1996 年 7 月 27 日から 29 日にかけて行った。観測期間中は一般風の弱い、 ほぼ快晴に近い天候であった。図 1 に観測対象地域を示す。市街地は瓦屋根つ 2 階建ての家屋 (高さ約 $7 \mathrm{~m}$ ) が大部分を占めており、都市キャノピーを形成している。自記温度計は湖岸を P1 として豊公園内に P2、長 㳋駅を越えて湖岸に垂直な県道（駅前通り）に沿って都市キャノピー層内の P3、以下、順番に市街地の端 P9 まで、距離約 $3790 \mathrm{~m}$ 間に地上 $1.2 \mathrm{~m}$ の高さに 9 点設置して気温の連続測定を行った。それぞれの観測地点 閒の距離を表 1 に示す。家屋の密集地帯は、長浜駅から東に約 $1500 \mathrm{~m}$ 四方にあり、その中心部に NTT の鉄 塔がある。P4 は NTT の鉄塔に最も近い場所にある。P6 から P8 地点までは県道に沿って住宅が存在し、そ の周囲は、ほとんどが水田である。P9 の周辺は水田になっていて、ここで都市が終わっている。また自記 温度計を湖岸から約 $1140 \mathrm{~m}$ の距離にある NTT の鉄塔に鉛直方向に 6 点設置した（図 2 ）。

風向風速計は豊公園の湖岸寄りに 2 高度 $(3.0 \mathrm{~m}$ と $5.0 \mathrm{~m})$ 、長浜市役所の屋上 $(17.0 \mathrm{~m})$ 、および NTT の鉄 塔 $(58.0 \mathrm{~m})$ に設置して連続測定を行った。他に全天日射計、大気放射計を長浜市役所屋上に設置して、それ ぞれ放射量を連続測定した。

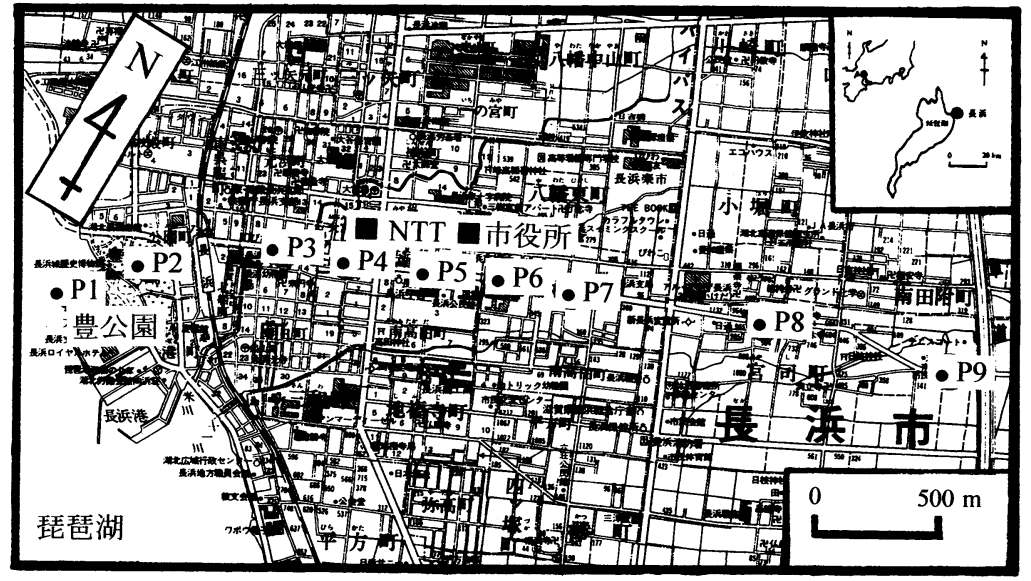

表 1 観測地点間の距離

\begin{tabular}{|c|c|}
\hline 区 間 & 距離 (m) \\
\hline $\begin{array}{l}\mathrm{P} 1-\mathrm{P} 2 \\
\end{array}$ & $\overline{390}$ \\
\hline $\begin{array}{l}\mathrm{P} 2-\mathrm{P} 3 \\
\end{array}$ & 480 \\
\hline P3-P4 & 260 \\
\hline P4-P5 & 290 \\
\hline P5-P6 & 410 \\
\hline P6-P7 & 290 \\
\hline P7-P8 & 790 \\
\hline P8-P9 & 880 \\
\hline
\end{tabular}

为 1 観測対象地域

3. 結果および考察

3 . 1 風ベクトル

図 3 は、豊公園の湖岸寄りに 2 高度 $(3.0 \mathrm{~m}$ と $5.0 \mathrm{~m})$ 、長浜市役所の屋上 $(17.0 \mathrm{~m})$ 、およびNTT の鉄塔 $(58.0$ $\mathrm{m})$ に設置した風向風速のベクトル図である。28 日は、どの高度でも似たような風系をなし、8時頃より吹 き始めた湖風が 18 時頃まで続き、それ以降は陸風に変わっていく椂子がわかる。29 日は、湖陸風の吹く基 本的な風系場に違いはないが、18 時の夕凪状態のときに、南西から西南西方向のかなり強い風が瞬間的に 入ってきている。これは、藤野・浅枝（1998）の解析では、大阪湾からの大規模な海風であると推察してい る。

\section{2 都市キャノピー層内の気温}

全ての観測データは、7月 29 日から 30 日を使用した。自記温度計のセンサー部分はアルミニウム製の日 射よけを付けてファンで強制通風した。観測期間中の県道での車の交通量は、昼間信号待ちで列を作るほか は貲带がなく、夜間 9 時以降では、1 分当たり 10 台以下であった。

図 4 および図 5 は都市キャノピー層内の気温の日変化を示す。データは、現象を見やすくするために 1 時 間ごとに、その時刻の 10 分間の平均気温をプロットし、データ間はスプライン関数で補間した。図中の琵 
琶湖の水温（Lake water）は、滋賀県衛生環境センターの1時間ごとのデータを用いている。日によって多 少の違いはあるが、28 日では水温は 0 時から 7 時填まで約 $28{ }^{\circ} \mathrm{C}$ で、ほぼ一定か、わずかに減少傾向にあり、

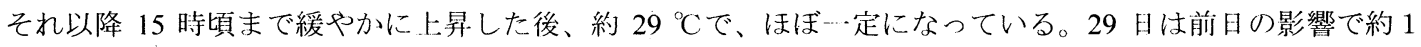
${ }^{\circ} \mathrm{C}$ 高く、7 時頃まで約 $29^{\circ} \mathrm{C}$ であった。その後は 28 日と同様な傾向で 15 時に約 $30^{\circ} \mathrm{C}$ 達し、一定になって いる。

気温は 28 日、29 日の両日とも P1 から P9 の各地点は 5 時頃より上昇を始め、16 時頃に日最高気温に達 した。 5 時から 16 時の時間帯に限定すれば、 28 日は湖水に最も近いP1 で 5 時に約 $27^{\circ} \mathrm{C}$ であった気温が、 16 時に約 $33{ }^{\circ} \mathrm{C} に$ 達した。この温度の風が都市キャノピー層に向かって吹いてくるが、豊公園内のP2 付近で 昇温するため、実質的にキャノピー層内に入ってくる風はP 2 の温度の風である。P2 の気温が P1

に近ければ近いほどキャノピー層を冷却する作用が強いと考えられるので、図 4 よりその時閒带を調べると 8 時から 14 時の 6 時間であることがわかった。この時間帯は P8 よりも都市の中心部である P4の方が気温 が低く、水田地帯のP9 とほぼ同じ温度で推移している。この現象は P4 付近まで湖風の泠却作用が及ぶが、 それ以降は次第に冷却効果が弱くなり、P8 付近では、ほとんど冷却効果がないことを示していると考えら れる。また図 3 からこの時間帯は湖風の最も強い時間帯になっている。29 日も、ほとんど同様な傾向を示 していた。

図 6 および図 7 は、湖風時の P1 から P9 地点の 1 時間ごとの 9 時から 16 時までの気温の断面を示す。 28 日、29日とも 9 時から 16 時の時間帯にP3 から P6 地点にかけてヒートアイランドが形成されている様子が わかる。11 時頃、湖風による冷却作用が最も強く、28 日は P5 付近に約 $33.1{ }^{\circ} \mathrm{C}$ のヒートアイランドのピー クが存在しているにもかかわらず、 $\mathrm{P} 8$ の $33.7^{\circ} \mathrm{C}$ に比べ約 $0.6{ }^{\circ} \mathrm{C}$ も低い。29 日の 11 時は、ヒートアイランド の中心が P8 付近にまで移動して、もはや都市の中心部にはヒートアイランドが存在していない。都市の中 心部は P4 付近であり、ヒートアイランドのピークもこの付近に出現してもよさそうである。類推として、 海陸風の存在する都市域が、海風によってヒートアイランドの中心が内陸部に移動するのと同様なメカニズ ムで、長浜辻のヒートアイランドの中心も湖風により風下側にずれている可能性が想定される。

図8および図 9 は、P1 からP9 各地点の気温と都市の終点である P9 の気温との差をそれぞれ 9 時から 2 時間ごとに 15 時まで求めたものである。図 6 および図 7 に比べ、より一層 P5 付近のヒートアイランドの 存在が明確になっている。2 8 日の 9 時および 11 時は、湖風により都市キャノピー屏が冷却されて、相対的 にP8 の温度が上がっているように見える。13 時は湖風の冷却作用が弱くなり、P5 から P8 地点までほとん ど差がなくなっている。15 時になると湖風の冷却作用も衰えて、都市キャノピー層外の $\mathrm{P} 2$ の気温も高くな り、都市部の P5 付近にヒートアイランドが顕著に出現している。29 日は 9 時に湖風の影響で P6 付近に七 ートアイランドの中心が存在し、11 時にはヒートアイランドの中心が P8 に移動している以外、28 日の傾 向と、ほとんど同じであった。

\section{3 都市境界層内の気温}

図 10 および図 11 は、NTTの鉄塔に地上からそれぞれ $13.0 \mathrm{~m} 、 25.0 \mathrm{~m} 、 38.5 \mathrm{~m} 、 45.0 \mathrm{~m} 、 51.5 \mathrm{~m}$ および $58.0 \mathrm{~m}$ の高度に自記温度計を設置して、気温の鉛㨁方向の日变化を表したものである。測定装置の管理は、都市キ ヤノピー層内の測定と同様にした。28 日、29日とも $13.0 \mathrm{~m}$ の高度のプロファイルが他の高度と比べ、波形 がかなり異なっている。これを都市キャノピー層内の気温のブロファイルと比較すると波形、位相ともほぼ 同じであるので、1 $13.0 \mathrm{~m}$ は都市キャノピー層内にあると考えられる。2 日に限定して考察するならば、13.0 m の波形の三ッ山に着目して、それと同形の波形を持つ高度を詳細に観察すると $25.0 \mathrm{~m} 、 38.0 \mathrm{~m} 、 45.0 \mathrm{~m}$ の 3 高度が兒つかった。しかし、波形の振幅も位相も異なっており、特に位相のずれに着日寸れれば、大気の鈆直 成分のフラックスの関与が示唆できるが、あくまでこれは推測の域を出ない。都市境界層内の気温は高度に

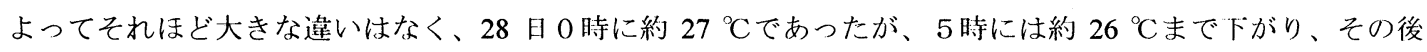
緩やかに上昇して 16 時に日最高気温に達した。16 時以降は、緩やかに減少していた。高度 $13.0 \mathrm{~m}$ の気温 


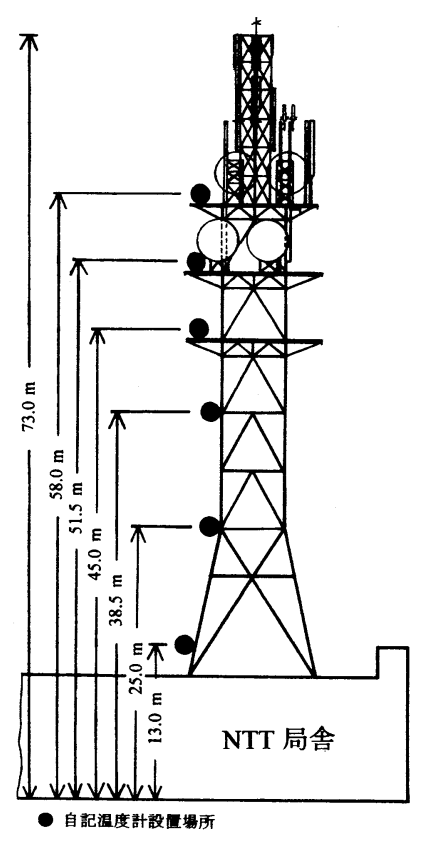

図 2 自記温度計の設置場所（NTT の鉄塔）

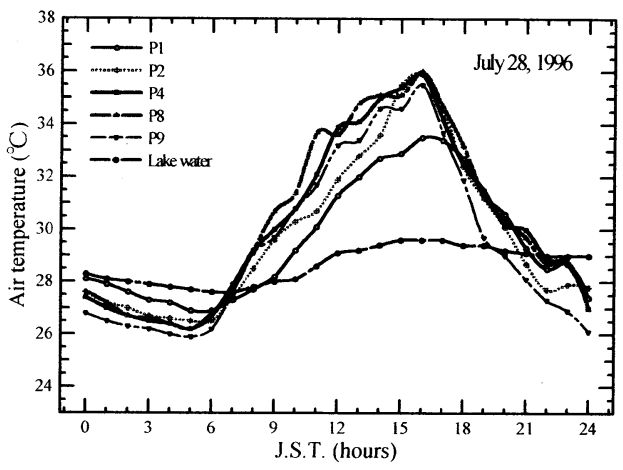

闵4都市キャノピー層内の気温の日変化（1）

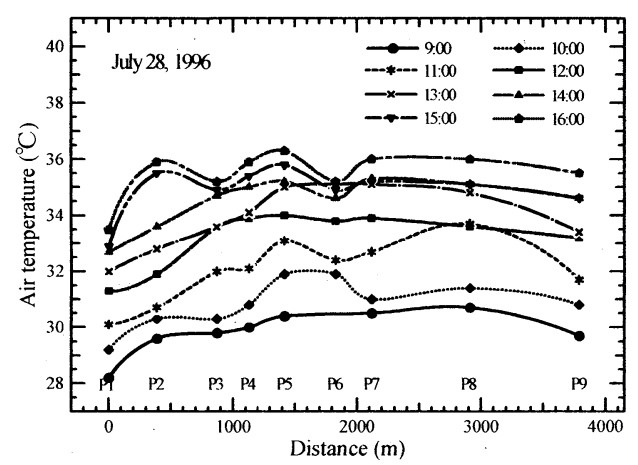

図6 キャノピー層内の父温の断的図（1）
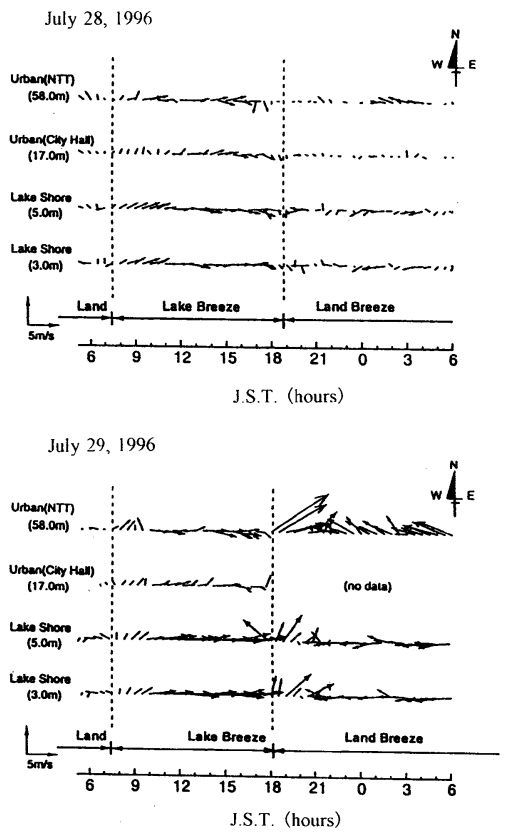

図3風ベクトルの日変化

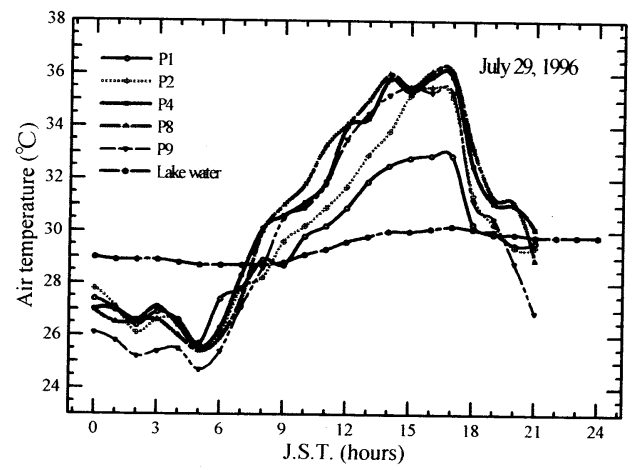

図 5 都市キャノピー層内の気温の日変化（2）

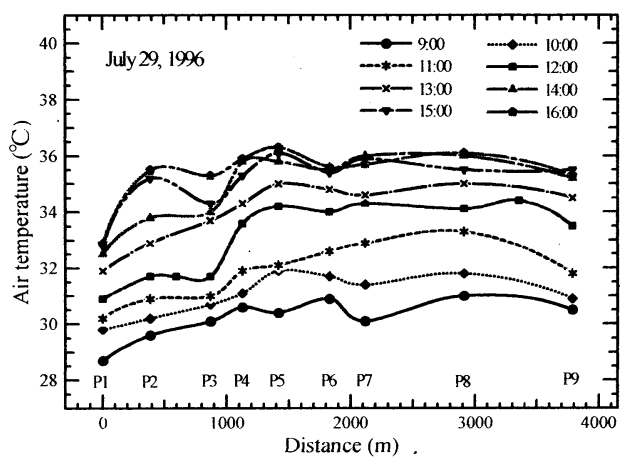

図7 キャノピー層内の父温の断面図（2） 


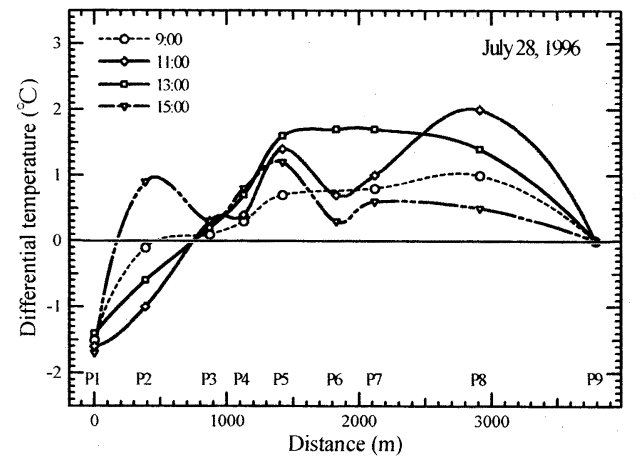

図 8 各地点とP9 の気温差（1）

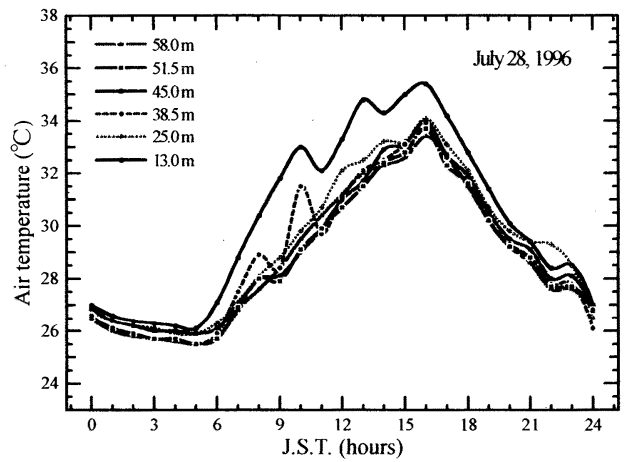

図 10 都市境界層内の気温の日変化（1）

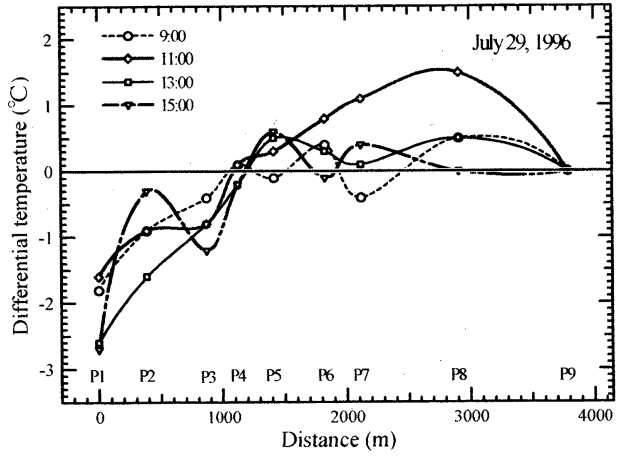

図 9 各地点とP9 の気温差（2）

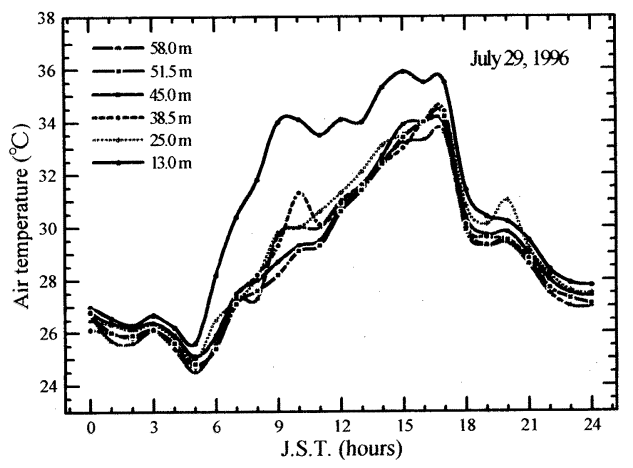

図 11 都市境界層内の気温の日変化 (2)

が、その他の高度に比べて、湖風の吹く時間帯にかなり高めである。NTT の鉄塔は、長浜市の中心部にあ り、この付近の家屋の建蔽率は、35\%から $45 \%$ \%をなっている（井下，1997）。このため湖風が都市キャ ノピー層内に進入しにくいのではないか、ということも考えられるが、陸風時では、都市キャノピー層内と 都市境界層内の気温に大きな違いが見られない。このことから陸風は、十分キャノピー層内にも進入してい ると考えられる。この現象の解釈として、藤野・浅枝（1998）は、数值シミュレーションによる局地風循環 の流線解析から、湖風時には琵琶湖周辺に下降流が生じ、このため昇温が起きているとした。

3.4 観測值とシミュレーションとの比較

近藤（1992）の簡略モデルを用いて、湖風が存在しない状態を再現して観測値と比較した。

$$
T(\mathrm{t})=T_{M}+B_{1} \cos (\omega t-a)
$$

ここで $T(\mathrm{t})$ : $\mathrm{time}=\mathrm{t}$ における気温、 $T_{M}$ :気温の日平均值、 $B:$ :気温の振幅、 $\omega$ :日変化の角速度、 $t$ :時間、 $\alpha$ :入力 放射量との位相差である。

使用する条件は、観測值（P4 地点）から求めた。観測値は、10 分ごとの平均気温である。初期条件とし て、 $t$ は図 12 から入力放射量が最大になる時刻を $t=0$ とした。図 13 は、その結果である。図 13 で 7 時より 15 時までシミュレーションの值の方が大きくなり、湖風時と対応している。夜間は湖水の熱容量が大きいため に、観測值の方が約 $3.7{ }^{\circ} \mathrm{C}$ 高くなっている。 


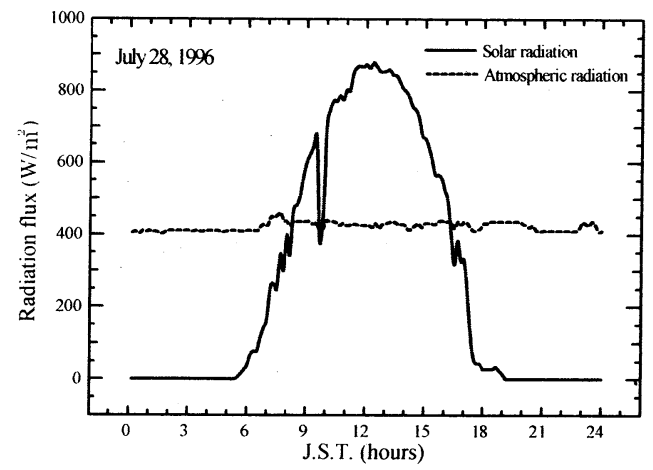

図 12 全天日射量および大気放射量

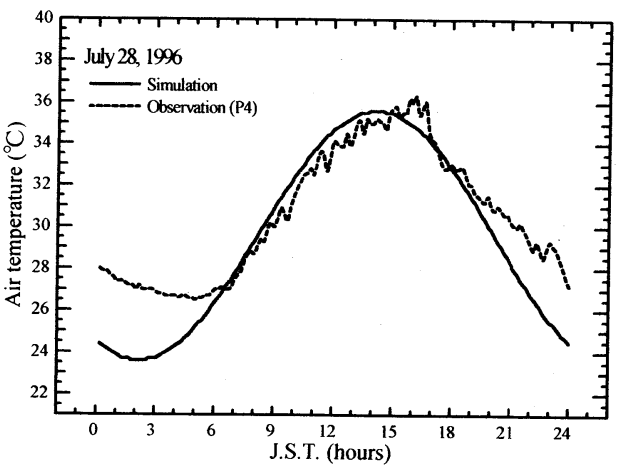

図 13 シミュレーションの結果

4.まとめ

1) P4 付近まで湖風の冷却作用が及ぶが、それ以降は次第に冷却効果が弱くなり、P8 付近では、ほとんど 冷却効果がない。

2）長浜市のヒートアイランドの中心は、湖風が存在しない時と比べて、湖風により風下側にずれている可 能性が想定される。

3 ）湖風時にシミュレーションと観測值の差が最も大きくなる時刻は、9 時 30 分頃であり、その差は約 1.8 ${ }^{\circ} \mathrm{C}$ なった。湖風時平均して約 $0.7{ }^{\circ} \mathrm{C}$ のャノピー層の気温低下が予想されるが、湖風による冷却作用 を考えるならば弱いと言える。日最高気温は、シミュレーションでは 14 時になるのに、観測值は 16 時 頃に到達している。これは、湖風による気温上昇に対する抑制効果であると考えられる。

謝辞

本研究は琵琶湖プロジェクト'96によって行われた。田中博春氏（東京都立大学大学院博士課程）はじめ、 観測に協力をして頂いた学生の皆様、そのほか観測に携わって頂いたすべての皆様に厚く御礼申し上げます。

《参考文献》

1 ）藤野毅・浅枝隆・和氣亜紀夫・孟岩：埼玉県南部地方を対象にした郊外型ヒートアイランドの特徵，水 工学論文集, 37, pp.591-596, 1993.

2）藤野毅・浅枝隆・中北英一：市街地スケール都市気象モデルによる風・熱環境評価の検討，水工学論文 集, 40, pp.231-236, 1996a.

3 ) 藤野毅・浅枝隆・和氣亜紀夫 : 夏季の都心部周辺における気温分布特性に関する数值実験, 地理学評論, 69-A 10, pp.817-831, 1996b.

4 ）藤野毅・浅枝隆・井下 雅博・坪松学・桐原博人・田中博春 : 湖岸の都市熱環境の観測とキャノピー内 外の熱境界層について, 水工学論文集, 41, pp.349-354, 1997.

5 ）藤野毅・浅枝隆：盆地内対流が都市に与える熱的影響の解析，水門・水資源学会研究発表会要旨集， pp.104-105, 1998.

6 ）井下雅博 : 赤外線サーモグラフィによる瓦屋根面温度測定と顕熱フラックス算定, 日本大学大学院生産 工学研究科修士論文, pp.54-56, 1997.

7 ）近藤純正 : 地表面温度と熱収支の周期解及びその応用，農業気象，48(3)，265-275，1992.

$8 ）$ 高木久之・北田敏廣 : 海風時に沿岸部の小丘により生成された乱流運動エネルギーの輸送特性とその下 流部への影響－ 2 次元 $\mathrm{k}-\varepsilon$ 乱流モデルによる解析一，天気，43，pp.289-302，1996. 